\title{
3D Printing of Clear Orthodontic Aligners: Where We Are and Where We Are Going
}

\author{
Cinzia Maspero ${ }^{1,2, *(1)}$ and Gianluca Martino Tartaglia ${ }^{1,2}$ \\ 1 Department of Biomedical, Surgical and Dental Sciences, School of Dentistry, University of Milan, \\ 20100 Milan, Italy; gmtartaglia@gmail.com \\ 2 Fondazione IRCCS Cà Granda, Ospedale Maggiore Policlinico, 20100 Milan, Italy \\ * Correspondence: cinzia.maspero@unimi.it
}

Received: 11 November 2020; Accepted: 13 November 2020; Published: 18 November 2020

\section{Editorial}

Clear orthodontic aligners were developed at the end of the 1990s [1]. The primary benefits are the improved esthetics and comfort, and the possibility to remove them when eating, brushing and flossing [2,3]. Different thermoplastic materials, or their combinations, are used for thermoforming clear aligners, including polyvinyl chloride, polyurethane, polyethylene terephthalate, and polyethylene terephthalate glycol [4-6]. However, a physical model (produced by 3D printing, stereolitography or material jetting) is needed for each aligner to be thermoformed and finally trimmed [7-9]. In addition, significant changes of material properties due to the thermoforming process have been reported. Ryu et al. [10] showed that thermoforming decreases the transparency of thicker material, and increases water absorption, water solubility and the surface hardness of the tested materials. While increased the higher thickness increases the delivered force and decreases the flexure modulus, the thermoforming process decreases both properties. The regular thickness of the aligner plays an important role in the magnitude of delivered forces: irregularities in the thickness influences the fitting accuracy of the aligner [7].

Moreover, other studies showed that temperature, humidity and salivary enzymes affect the aligner, modifying its original shape and mechanical behavior [11-14]. The described changes of the aligner caused by thermoforming process and intraoral environment then might influence the treatment efficacy. An alternative to the described conventional fabrication is now approaching the direct 3D printing of clear aligners using dedicated materials [15].

The 3D printing technologies are currently increasing their role for clinical and research purposes in dentistry. Surgical implant guides, prosthodontics, restorative dentistry, orthodontics, implantology and instrument manufacturing have been revolutionized by 3D printing [15-17]. This technology allows to manufacture components layer-by-layer, instead of common manufacturing methods that rely on molding, machining or other subtractive methods [18,19]. Acrylonitrile-butadiene-styrene plastic, stereolithography materials (epoxy resins), polylactic acid, polyamide (nylon), glass-filled polyamide, silver, steel, titanium, photopolymers, wax, and polycarbonate are commonly used materials for 3D printing in orthodontics [20-24].

This technology can be used for direct printing of clear aligners, too [15]. Despite today's improvement of 3D printing technology, the lowering of its cost and its use in other fields of dentistry, a limited number of studies can be found describing the direct 3D printing of clear aligners.

Multiple 3D printing processes may be used for the direct printing of clear aligners, such as fused deposition modelling, selective laser sintering, selective laser melting, direct pellets fused deposition, stereolithography, multi-jet photo cured polymer process, or continuous liquid interface production technology [15,25-27]. However, 3D printing by photo-polymerization from clear resin is currently the most suitable option. 
A study by Jindal et al. [28] presented a successfully 3D printed $0.75 \mathrm{~mm}$ thick clear aligner using Dental Long Term (LT) ${ }^{\circledR}$ clear resin (Form Labs, Somerville, MA, USA) and compared its mechanical and geometrical properties to a conventionally manufactured thermoformed Duran clear dental aligners. Authors suggested that 3D printed resin-cured clear dental aligners are more suitable because they have better geometric accuracy and mechanical resistance. Dental LT resin is an approved Class IIa biocompatible material with high resistance to fracture and it is ideal for hard splints, retainers, and other rigid direct-printed long-term orthodontic appliances. Its use for a direct 3D printing of clear aligner was not described before, and authors are omitting the major limitation of their study-the lack of clinical data to evaluate performance of Dental LT resin and its durability during the use by patients.

The cytotoxicity of directly 3D printed clear aligners from three different materials was also studied [29]. Three different aligners were compared: printed using Accura 60 ${ }^{\circledR}$ SLA (3D Systems, Rockhill, South Carolina), Dental LT ${ }^{\circledR}$ clear resin (Form Labs, Somerville, MA, USA) and Invisalign ${ }^{\circledR}$ (Aligntech, San Jose, CA, USA). Similarly, Dental LT resin and Accura $60^{\circledR}$ SLA are not approved for direct printing of 3D aligners and were not previously tested and described for this purpose. The study confirmed that Invisalign ${ }^{\circledR}$ material was the least cytotoxic, followed by Dental LT ${ }^{\circledR}$ and Accura $60^{\circledR}$. However, to our knowledge, Invisalign ${ }^{\circledR}$ aligners are not directly 3D printed. The lack of clinical data is similarly the main limitation of this study.

In early 2018, EnvisionTEC Inc. announced launch of E-Ortholign, a new material for the direct 3D printing of clear thermoformed aligners [27,30-32]. This clear resin is marketed as biocompatible, stable, flexible and strong material for the direct 3D printing of esthetic retainers [30,33,34]. Nowadays, there is no marketed and approved resin suitable for the direct 3D printing of clear aligners.

Direct 3D printing of aligners offers several advantages over conventional fabrication: edges are softer and do not need trimming or smoothing; undercuts analysis is digitally defined; intra-aligner thickness is customizable, which may reduce the need of attachments, reducing the transparency of clear aligners [35].

Author Contributions: Conceptualization, C.M. and G.M.T.; writing—original draft preparation, C.M.; writing—review and editing, C.M. and G.M.T.; All authors have read and agreed to the published version of the manuscript.

Funding: This research received no external funding.

Conflicts of Interest: The authors declare no conflict of interest.

\section{References}

1. Leonardi, R. Cone-beam computed tomography and three-dimensional orthodontics. Where we are and future perspectives. J. Orthod. 2019, 46, 45-48. [CrossRef]

2. Shalish, M.; Cooper-Kazaz, R.; Ivgi, I.; Canetti, L.; Tsur, B.; Bachar, E.; Chaushu, S. Adult patients' adjustability to orthodontic appliances. Part I: A comparison between Labial, Lingual, and Invisalign ${ }^{\mathrm{TM}}$. Eur. J. Orthod. 2012, 34, 724-730. [CrossRef]

3. Maspero, C.; Cavagnetto, D.; Abate, A.; Cressoni, P.; Farronato, M. Effects on the Facial Growth of Rapid Palatal Expansion in Growing Patients Affected by Juvenile Idiopathic Arthritis with Monolateral Involvement of the Temporomandibular Joints: A Case-Control Study on Posteroanterior and Lateral Cephalograms. J. Clin. Med. 2020, 9, 1159. [CrossRef] [PubMed]

4. Ercoli, F.; Tepedino, M.; Parziale, V.; Luzi, C. A comparative study of two different clear aligner systems. Prog. Orthod. 2014, 15, 31. [CrossRef] [PubMed]

5. Pithon, M.M. A modified thermoplastic retainer. Prog. Orthod. 2012, 13, 195-199. [CrossRef] [PubMed]

6. Maspero, C.; Farronato, M.; Bellincioni, F.; Annibale, A.; Machetti, J; Abate, A.; Cavagnetto, D. Three-Dimensional Evaluation of Maxillary Sinus Changes in Growing Subjects: A Retrospective Cross-Sectional Study. Materials 2020, 13, 1007. [CrossRef]

7. Weir, T. Clear aligners in orthodontic treatment. Aust. Dent. J. 2017, 62 (Suppl. S1), 58-62. [CrossRef]

8. Martorelli, M.; Gerbino, S.; Giudice, M.; Ausiello, P. A comparison between customized clear and removable orthodontic appliances manufactured using RP and CNC techniques. Dent. Mater. 2013, 29, e1-e10. [CrossRef] 
9. Maspero, C.; Abate, A.; Bellincioni, F.; Cavagnetto, D.; Lanteri, V.; Costa, A.; Farronato, M. Comparison of a tridimensional cephalometric analysis performed on 3T-MRI compared with CBCT: A pilot study in adults. Prog. Orthod. 2019, 20, 40. [CrossRef]

10. Ryu, J.-H.; Kwon, J.-S.; Jiang, H.B.; Cha, J.-Y.; Kim, K.-M. Effects of thermoforming on the physical and mechanical properties of thermoplastic materials for transparent orthodontic aligners. Korean J. Orthod. 2018, 48, 316-325. [CrossRef]

11. Gerard Bradley, T.; Teske, L.; Eliades, G.; Zinelis, S.; Eliades, T. Do the mechanical and chemical properties of InvisalignTM appliances change after use? A retrieval analysis. Eur. J. Orthod. 2016, 38, 27-31. [CrossRef] [PubMed]

12. Ryokawa, H.; Miyazaki, Y.; Fujishima, A.; Miyazaki, T.; Maki, K. The mechanical properties of dental thermoplastic materials in a simulated intraoral environment. Orthod. Waves 2006, 65, 64-72. [CrossRef]

13. Maspero, C.; Abate, A.; Cavagnetto, D.; Fama, A.; Stabilini, A.; Farronato, G.; Farronato, M. Operculectomy and spontaneous eruption of impacted second molars: A retrospective study. J. Biol. Regul. Homeost. Agents 2019, 33, 1909-1912. [CrossRef] [PubMed]

14. Fama, A.; Cavagnetto, D.; Abate, A.; Mainardi, E.; De Filippis, A.; Esposito, L. Treatment of dental dilacerations. Narrative review. Dent. Cadmos 2020, in press.

15. Shivapuja, P.; Shah, D.; Shah, N.; Shah, S. Direct 3D-Printed Orthodontic Aligners with Torque, Rotation, and Full Control Anchors. U.S. Patent 10,179,035, 15 January 2019.

16. Maspero, C.; Farronato, M.; Bellincioni, F.; Cavagnetto, D.; Abate, A. Assessing mandibular body changes in growing subjects: A comparison of CBCT and reconstructed lateral cephalogram measurements. Sci. Rep. 2020, in press. [CrossRef] [PubMed]

17. Maspero, C.; Giannini, L.; Riva, R.; Tavecchia, M.G.; Farronato, G. Nasal cycle evaluation in 10 young patients: Rhynomanometric analysis. Mondo Ortod. 2009, 34, 263-268. [CrossRef]

18. Prasad, S.; Kader, N.A.; Sujatha, G.; Raj, T.; Patil, S. 3D printing in dentistry. J. 3D Print. Med. $2018,2$. [CrossRef]

19. Abate, A.; Cavagnetto, D.; Fama, A.; Bellincioni, F.; Assandri, F. Efficacy of Operculectomy in the Treatment of 145 Cases with Unerupted Second Molars: A Retrospective Case-Control Study. Dent. J. 2020, 8, 65. [CrossRef]

20. Nguyen, T.; Jackson, T. 3D technologies for precision in orthodontics. Semin. Orthod. 2018, 24, $386-392$. [CrossRef]

21. Maspero, C.; Fama, A.; Cavagnetto, D.; Abate, A.; Farronato, M. Treatment of dental dilacerations. J. Biol. Regul. Homeost. Agents 2019, 33, 1623-1627.

22. Farronato, G.; Maspero, C.; Giannini, L.; Farronato, D. Occlusal splint guides for presurgical orthodontic treatment. J. Clin. Orthod. 2008, 42, 508-512. [PubMed]

23. Farronato, G.; Giannini, L.; Galbiati, G.; Maspero, C. A 5-year longitudinal study of survival rate and periodontal parameter changes at sites of dilacerated maxillary central incisors. Prog. Orthod. 2014, 15, 3. [CrossRef] [PubMed]

24. Esposito, L.; Poletti, L.; Maspero, C.; Porro, A.; Pietrogrande, M.C.; Pavesi, P.; Dellepiane, R.M.; Farronato, G. Hyper-IgE syndrome: Dental implications. Oral Surg. Oral Med. Oral Pathol. Oral Radiol. 2012, 114, 147-153. [CrossRef] [PubMed]

25. Maspero, C.; Abate, A.; Cavagnetto, D.; Morsi, M.; Fama, A.; Farronato, M. Available Technologies, Applications and Benefits of Teleorthodontics. A Literature Review and Possible Applications during the COVID-19 Pandemic. J. Clin. Med. 2020, 9, 1891. [CrossRef] [PubMed]

26. Abate, A.; Cavagnetto, D.; Fama, A.; Matarese, M.; Lucarelli, D.; Assandri, F. Short term effects of rapid maxillary expansion on breathing function assessed with spirometry: A case-control study. Saudi Dent. J. 2020. [CrossRef]

27. Farronato, G.; Maspero, C.; Esposito, L.; Briguglio, E.; Farronato, D.; Giannini, L. Rapid maxillary expansion in growing patients. Hyrax versus transverse sagittal maxillary expander: A cephalometric investigation. Eur. J. Orthod. 2011, 33, 185-189. [CrossRef] [PubMed]

28. Jindal, P.; Juneja, M.; Siena, F.L.; Bajaj, D.; Breedon, P. Mechanical and geometric properties of thermoformed and 3D printed clear dental aligners. Am. J. Orthod. Dentofac. Orthop. 2019, 156, 694-701. [CrossRef]

29. Mohnish Kumar, S. Cytotoxicity of 3D Printed Materials: An In Vitro Study. Master's Thesis, Sri Ramakrishna Dental College and Hospital, Coimbatore, India, 2019. 
30. Gao, T.; Gillispie, G.J.; Copus, J.S.; Pr, A.K.; Seol, Y.-J.; Atala, A.; Yoo, J.J.; Lee, S.J. Optimization of gelatin-alginate composite bioink printability using rheological parameters: A systematic approach. Biofabrication 2018, 10, 34106. [CrossRef]

31. Farronato, M.; Cavagnetto, D.; Abate, A.; Cressoni, P.; Fama, A.; Maspero, C. Assessment of condylar volume and ramus height in JIA patients with unilateral and bilateral TMJ involvement: Retrospective case-control study. Clin. Oral Investig. 2020, 24, 2635-2643. [CrossRef]

32. Lanteri, V.; Farronato, M.; Ugolini, A.; Cossellu, G.; Gaffuri, F.; Parisi, F.M.R.; Cavagnetto, D.; Abate, A.; Maspero, C. Volumetric Changes in the Upper Airways after Rapid and Slow Maxillary Expansion in Growing Patients: A Case-Control Study. Materials 2020, 13, 2239. [CrossRef]

33. Farronato, G.; Giannini, L.; Galbiati, G.; Maspero, C. Comparison of the dental and skeletal effects of two different rapid palatal expansion appliances for the correction of the maxillary asymmetric transverse discrepancies. Minerva Stomatol. 2012, 61, 45-55. [PubMed]

34. Ferrario, V.F.; Sforza, C.; Tartaglia, G.; Barbini, E.; Michielon, G. New television technique for natural head and body posture analysis. Cranio 1995, 13, 247-255. [CrossRef] [PubMed]

35. Available online: https://www.donatellosmile.com (accessed on 2 November 2020).

Publisher's Note: MDPI stays neutral with regard to jurisdictional claims in published maps and institutional affiliations.

(C) 2020 by the authors. Licensee MDPI, Basel, Switzerland. This article is an open access article distributed under the terms and conditions of the Creative Commons Attribution (CC BY) license (http://creativecommons.org/licenses/by/4.0/). 